\title{
The influence of recycled concrete aggregates in pervious concrete
}

\section{Estudo da influência dos agregados de concreto reciclado em concretos permeáveis}
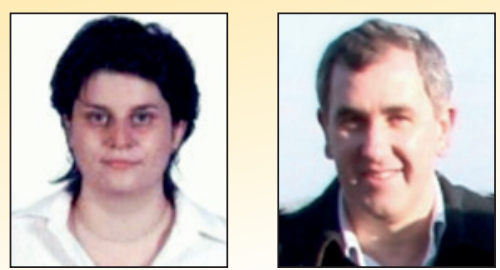

L. M. TAVARES a

lisiane.morfeo@terra.com.br

C. S. KAZMIERCZAK claudiok@unisinos.br

\begin{abstract}
The expansion of urban areas under constant changes in the hydrological cycle directly affects the drainage of rainwater. The problems of urban drainage become major engineering problems to be solved in order to avoid negative consequences for local populations. Another urban problem is the excessive production of construction and demolition waste (CDW), in which, even with a increasingly policy of waste management , have been an end up being thrown in inappropriate disposal sites. Alternatively aiming to a minimization of the problems presented, we propose the study of permeable concrete using recycled concrete aggregate. In this study, there were evaluated the performance of concrete by means of permeability, consistency, strength, and interface conditions of the materials . Satisfactory relationships of resistance/permeability of concrete with recycled aggregate in relation to the concrete with natural aggregates was obtained, showing their best potential.
\end{abstract}

Keywords: waste, pervious concrete, recycled concrete aggregates.

\section{Resumo}

A expansão de áreas urbanas força a uma constante alteração do ciclo hidrológico, que por sua vez afeta diretamente a drenagem das águas pluviais. Os problemas de drenagem urbana tornam-se grandes problemas de engenharia a serem resolvidos para evitar consequências nefastas para as populações locais. Outro problema urbano é a demasiada produção de resíduos de construção civil (RCC), pois apesar da criação de políticas para o gerenciamento destes resíduos ainda há grande quantidade de RCC sendo lançados em locais inadequados de disposição. Como uma alternativa de minimização dos problemas apresentados, propõem-se o estudo de concreto permeável com o uso de agregados reciclados de concreto como uma alternativa para pavimentação. Neste estudo foi avaliada a eficiência dos concretos por meio de ensaio de permeabilidade, consistência, resistência mecânica e as condições de interface. Obtiveram-se satisfatórias relações de resistência/permeabilidade dos concretos com agregado reciclado em relação aos concretos com agregados naturais, mostrando o seu grande potencial de uso.

Palavras-chave: resíduos, concreto permeável, agregados reciclados de concreto. 


\section{Introduction}

Worldwide, large cities are characterized by numerous buildings and impermeable paved areas, in sheer contrast with the main features of natural environments. So, the typical manifestations of urban occupation, mostly impermeable elements like roofs, sidewalks, streets, and parking lots affect not only the stormwater volumes involved, but also the quality of local hydrological cycles as a whole. As a result of soils becoming increasingly impervious, floods are now seen as some of the main problems faced by inhabitants of urban environments. An interesting example is the fast urbanization process witnessed in Brazil towards the end of the $20^{\text {th }}$ century, which has influenced quality of life in large cities significantly and, in several aspects, has risen concerns associated with urban floods.

When water is prevented from seeping into the soil, runoffs and the return of water to the water table become problematic in urban areas, altering the characteristics of river and canal beds and increasing volumes and frequency of floods. Unfortunately, floods also wash away litter, affecting water quality directly. Most solutions adopted by authorities include the construction of drainage networks that merely transfer the flood downstream, with no assessment of the actual efficacy of such systems. Current trends in the design of urban drainage systems point to the search for new technologies aimed at improving seepage and reducing surface runoffs [1].

Flood control measures may be classified as structural and nonstructural. Structural measures are comparatively costly, since they involve special construction works or the use of specific equipment and technologies. In turn, non-structural measures include inexpensive managerial decisions to tackle the reasons that may trigger or worsen such problems. Generally speaking though, important control efforts consist of on-site stormwater detention works (which nevertheless control only peak flows), the use of special seepage areas (which receive runoffs of impervious areas and help recover basin seepage

\section{Figure 1 - Typical aspect of pervious concrete}

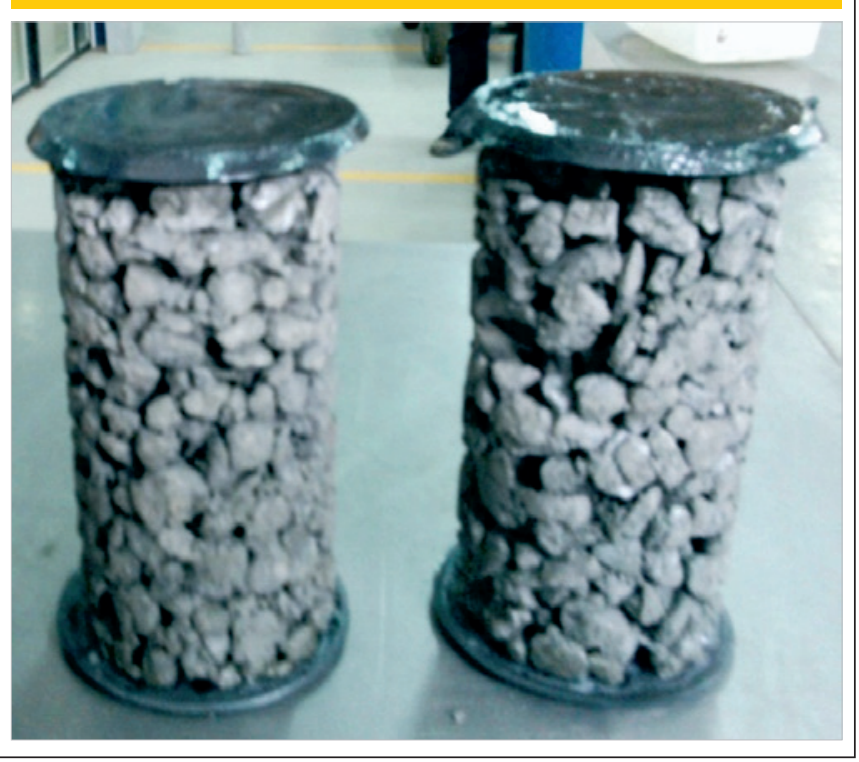

capacity), and the development of pervious pavements. In turn, micro- and macro-drainage measures include detention and retention strategies. Briefly, detention is based on the use of dry basins designed as an integrating feature of urban landscapes, while retention works maintain a permanent pool and are used to not only control flow peaks, but also assess water quality. However, the greatest difficulty in the design and construction of these reservoirs is the amount of litter carried by stormwater flows, which obstructs drainage inlets [2,3]. In this scenario, pervious pavements stand as promising alternatives to reduce surface runoffs, favoring seepage and water retention in soils.

The materials most commonly used to produce pervious pavements are concrete and asphalt. The present study discusses an alternative material, recycled concrete aggregates (RCA). The extraction of natural raw resources and the processing thereof to produce construction materials pose considerable environmental impacts. Yet another cause of environmental concern is the disposal of construction and demolition waste (CDW). In particular, the main problem associated with CDW lies in the fact that it is often disposed of in clandestine landfills, worsening environmental impacts and requiring considerable public financial resources to implement appropriate management solutions.

In Brazil, an important breakthrough in the management of CDW was the passing of specific regulation [4], which lists CDW as Class A waste and outlines the procedures to recycle it as construction aggregate during the preparation of fresh materials in a building site. The main advantages of recycling CDW include the prospect of prolonging the lifespan of alarmingly scarce extant natural extraction sites, by replacing natural aggregates with recycled materials. Another upside is that sometimes recycling affords to produce building materials at low associated costs [5].

Recycled CDW aggregates vary considerably in fragment size, and are more porous than the crushed rock aggregates usually employed in the production of concrete mixtures. As expected, such high porosity of CDW is believed to lead to more porous concretes, reducing mechanical resistance and affecting the material's protective role against the rusting of steel assemblies, with serious structural hazards. However, what is perceived as a disadvantage in reinforced concrete built with recycled CDW aggregates may be seen as a positive attribute in the design of pervious pavements, when the aim is exactly to improve drainage potential of materials.

Perhaps the main advantage of pervious concrete lies in its use in sustainable buildings, since the material is the primary element in a low-impact technology increasingly used by building contractors as a means to protect water quality [6]. The appropriate use of pervious concrete is one of the best management practices listed by the US Environmental Protection Agency as important measures to control pollution of rivers.

Pervious pavements have been used in the USA and Europe since the mid-1970s. These materials may be classified into three categories, namely porous asphalt pavement, porous concrete pavement (monolithic), and concrete block pavements [7]. As a rule, concrete pavement is expected to have high porosity, due to the significant number of voids strongly connected to the coarse aggregates used. Typically little or no fine aggregates are added to pervious concrete mixtures. When these aggregates are used, the aim is solely to cover the large aggregate particles, preserving the communication between voids (Figure 1). 


\section{Table 1 - Characterization of natural and RCA aggregates}

\begin{tabular}{|cccc}
\hline Assay & Standard & Natural & Recycled \\
\hline Largest diameter (characteristic) & NBR NM 248:2003(11) & $19 \mathrm{~mm}$ & $25 \mathrm{~mm}$ \\
\hline Fineness modulus & NBR NM 248:2003 & $1.77 \mathrm{~mm}$ & $6.78 \mathrm{~mm}$ \\
Specific weight (dry) & NBR NM 53:2009(12) & $2.74 \mathrm{~g} / \mathrm{cm}^{3}$ & $1.94 \mathrm{~g} / \mathrm{cm}^{3}$ \\
Specific weight (wet) & NBR NM 53:2009 & $2.77 \mathrm{~g} / \mathrm{cm}^{3}$ & $2.10 \mathrm{~g} / \mathrm{cm}^{3}$ \\
Specific weight (apparent) & NBR NM 53:2009 & $2.84 \mathrm{~g} / \mathrm{cm}^{3}$ & $2.30 \mathrm{~g} / \mathrm{cm}^{3}$ \\
Unit weight & NBR NM 45:2006(13) & $1.51 \mathrm{~g} \mathrm{~cm}^{3}$ & $1.22 \mathrm{~g} / \mathrm{cm}^{3}$ \\
Water absorption & - & $1.33 \%$ & $7.91 \%$ \\
Void index & NBR NM 45:2006 & $45 \%$ & $36.42 \%$ \\
\hline
\end{tabular}

Pervious concrete has lower mechanical resistance, compared with common concrete prepared with the same amount of cement. In addition, the material is more susceptible to fragmentation under moving traffic loads. This kind of pavement is conventionally used in parking lots, streets in residential areas, light traffic areas, and sidewalks $[8,9]$.

Considering the need for more information on pavement perviousness and concrete recycling, this study investigates pervious concrete prepared with RCA, a specific type of CDW. The efficiency of pervious concretes was evaluated based on perviousness, consistency, and mechanical resistance characteristics analyzed in laboratory experiments, assessing the interface between RCA and different concrete mixtures.

\section{Materials and experimental program}

Two aggregates were tested, natural crushed basalt, and RCA obtained during the crushing of prefabricated concrete waste $\left(f_{p k}=30 \mathrm{MPa}\right)$ from a local company. The concrete waste was crushed by milling and sifted to segregate fine aggregates. Then, the concrete aggregates were stored in the laboratory upon use. The characterization of the coarse aggregate used is shown in Table 1. Brazilian Portland cement CP IV-32 was used as water-activated binder, analyzed following the Brazilian standard NBR 5736:1999 [10].

Since there are no established methodologies to define the composition of pervious concrete, it was reviewed earlier works in the effort to identify the most common compositions used [14-18]. Based on these data, we developed mixtures containing different amounts of RCA $\left(336,350,398,485\right.$, and $\left.539 \mathrm{~kg} / \mathrm{m}^{3}\right)$ and coarse aggregate $\left(1289,1297,1307,1400\right.$, and $1628 \mathrm{~kg} / \mathrm{m}^{3}$ ) looking for the one with the best relationship between cohesion of fresh mixture and resistance. This mixture was used in the subsequent stages of this study. The water levels were calculated considering water-to-binder ratios of $0.3 \pm 0.03$ and $0.4 \pm 0.03$ for mixtures prepared with natural and RCA aggregates respectively. Mixtures were prepared with $100 \%$ natural aggregate, equal amounts $(50 \%)$ of natural aggregate and RCA, and 100\% RCA Short (12 mm) and long $(24 \mathrm{~mm})$ fiberglass fibers were added to three RCA mixtures to improve mechanical characteristics. The water-to-binder ratios used are shown in Table 2.

Each mixture was submitted to the slump test in a VeBe consis- tometer following the standards $\mathrm{ACl} 211.3 \mathrm{R}-02$ [19] and DNIT $064 / 2004$ [20]. This procedure is used to analyze the consistency of very dry concretes, since the conventional slump test usually produces zero slump in the analysis of pervious concretes. Next, $f_{p k}$ was determined using cylindrical blocks $20 \mathrm{~cm}$ tall and $10 \mathrm{~cm}$ across (set as three layers), each one submitted to a vibrating table for $5 \mathrm{~s}$. Samples were then removed from the wet chamber and their $f_{p k}$ was determined at ages of 3, 7, and 28 days, according to Brazilian standard NBR 5739:2007 [21]. Strength values are expressed as means of three repeats for each mixture. These strength means were used as input in the equation suggested in the Brazilian standard NBR 9781:2003 [22] to calculate $f_{p k}$ [22]. The Student's $t$ coefficient for $\mathrm{n}=3$ at $80 \%$ confidence was 0.92 . The standard cited considers that $f_{p k}$ has normal distribution; so, $f_{p k}$ could be calculated using Equation 1.

$$
f_{p k}=f_{p}-t . s
$$

where $f_{p k}$ is the characteristic strength (MPa), $f_{p}$ is the mean strength $(\mathrm{MPa}), t$ is the Student's $t$ coefficient, and $s$ is the standard deviation of the sample (MPa).

Water absorption was determined based on the void index obtained in an immersion test and the specific weight of 28-day cured concrete samples $20 \mathrm{~cm}$ tall and $10 \mathrm{~cm}$ across, according to the Brazilian standard NBR 9778:2009 [23]. Three repeats were carried out for each mixture. Perviousness of all mixtures was determined using cylindrical samples $150 \mathrm{~mm}$ tall and measuring 97.7 $\mathrm{mm}$ in inside diameter (three repeats) and a falling-head permeameter, following the Brazilian standard NBR 14545:2000 [24]. Perviousness is measured based on the variation in water head inside a tube for different times. The perviousness coefficient is calculated using Darcy's law (Equation 2).

$$
k=\frac{V x l}{A x T x \Delta H}
$$

where $k$ is the perviousness coefficient of a sample $(\mathrm{m} / \mathrm{s}), I$ is sam- 


\section{Table 2 - Composition of the concrete mixtures}

\begin{tabular}{|c|c|c|c|c|c|c|}
\hline \multirow[t]{2}{*}{ Mixtures } & Cement & Water & $\begin{array}{l}\text { Natural } \\
\text { aggregate }\end{array}$ & $\begin{array}{c}\text { RCA } \\
\text { aggregate }\end{array}$ & $\begin{array}{c}\text { Fiber } \\
\left(\mathrm{kg} / \mathrm{m}^{3}\right)\end{array}$ & Natural \\
\hline & $\left(\mathrm{kg} / \mathrm{m}^{3}\right)$ & $\left(\mathrm{kg} / \mathrm{m}^{3}\right)$ & $\left(\mathrm{kg} / \mathrm{m}^{3}\right)$ & $\left(\mathrm{kg} / \mathrm{m}^{3}\right)$ & $12 \mathrm{~mm}$ & $24 \mathrm{~mm}$ \\
\hline N-330 & 336.00 & 107.00 & 1628.00 & 0.00 & 0.00 & 0.00 \\
\hline N-350 & 350.00 & 105.00 & 1400.00 & 0.00 & 0.00 & 0.00 \\
\hline $\mathrm{N}-400$ & 398.00 & 133.00 & 1307.00 & 0.00 & 0.00 & 0.00 \\
\hline$N-540$ & 539.00 & 175.00 & 1289.00 & 0.00 & 0.00 & 0.00 \\
\hline NR-400 & 398.00 & 133.00 & 653.50 & 653.50 & 0.00 & 0.00 \\
\hline R-400 & 398.00 & 161.60 & 0.00 & 1307.00 & 0.00 & 0.00 \\
\hline R-480 & 485.00 & 188.57 & 0.00 & 1297.00 & 0.00 & 0.00 \\
\hline Rs-400 & 398.00 & 161.60 & 0.00 & 1307.00 & 2.00 & 0.00 \\
\hline RI-400 & 398.00 & 161.60 & 0.00 & 1307.00 & 0.00 & 6.00 \\
\hline Rsl-400 & 398.00 & 161.60 & 0.00 & 1307.00 & 2.00 & 2.00 \\
\hline
\end{tabular}

ple height $(m), A$ is the area of the sample where water flows on $\left(\mathrm{m}^{2}\right), \Delta \mathrm{H}$ is the hydraulic head $(\mathrm{m}), T$ is water flow time $(\mathrm{s})$, and $V$ is the sample's volume $\left(\mathrm{m}^{3}\right)$.

The analysis of the microstructure of the cement paste was carried out using the samples $\mathrm{N}-400$ and R-400. Samples identification was based on the type of aggregate $(\mathrm{N}-$ natural, $\mathrm{R}$ - recycled, $\mathrm{Rs}$ - recycled with short fibers, $\mathrm{RI}$ - recycled with long fibers) and cement consumption (in $\mathrm{kg} / \mathrm{m} 3$ ). The two concretes were prepared with identical consumption of cement, water-to-binder ratio, and amount of aggregate (natural and recycled, in N-400 and R-400, respectively). In order to observe the integrity of surfaces, samples of concretes were sawn off using a slow, precision rotary saw. Then they were polished, dried in a desiccator, and gold-plated. Microstructural analysis was carried out using a scanning elec- tron microscope (Evols15, Zeiss) and an optical microscope in the Technological Assays and Functional Safety Laboratories (itt Fuse), UNISINOS, Brazil.

\section{Results and discussions}

The compressive strength assays were carried out in the Laboratory of Construction Materials (LMC), UNISINOS. Means and standard deviations and $f_{p k}$ are shown in Table 3.

All $f_{p k}$ values measured in 28-day-old blocks were within the $2.8-28 \mathrm{MPa}$ range expected for pervious concrete, as defined in the standard $\mathrm{ACl} 522 \mathrm{R}$ [25]. However, the values observed are not high enough to afford using these concretes in sites exposed to heavy traffic. The Brazilian standard NBR 9781:2013

\begin{tabular}{|c|c|c|c|c|}
\hline \multicolumn{5}{|c|}{$\begin{array}{l}\text { Table } 3 \text { - Mean compressive strength }\left(f_{p k}\right) \text { and standard deviations } \\
\text { of the cement mixtures evaluated using the Brazilian standard NBR 9781:2013 }\end{array}$} \\
\hline Mixłures & 3 days & 7 days & 28 days & ${ }^{*}{ }^{*} f_{p k}(\mathrm{MPa})$ \\
\hline N-330 & $4.07(1.41)$ & $4.77(0.26)$ & $10.83(1.64)$ & 9.32 \\
\hline$N-350$ & $10.13(0.82)$ & $10.60(1.64)$ & $14.60(2.92)$ & 11.91 \\
\hline $\mathrm{N}-400$ & $10.37(1.18)$ & $13.37(2.16)$ & $21.83(1.53)$ & 20.42 \\
\hline N-540 & $17.33(2.79)$ & $19.50(2.04)$ & $21.10(1.81)$ & 19.43 \\
\hline NR-400 & $7.17(1.04)$ & $6.93(1.41)$ & $11.10(2.30)$ & 8.98 \\
\hline R-400 & $9.87(1.29)$ & $10.43(1.33)$ & $11.63(1.28)$ & 10.45 \\
\hline $\mathrm{R}-480$ & $8.20(2.10)$ & $11.57(1.38)$ & $20.67(0.85)$ & 19.89 \\
\hline Rs-400 & $10.47(0.98)$ & $14.27(1.24)$ & $19.10(1.47)$ & 17.75 \\
\hline RI-400 & $11.33(2.12)$ & $14.93(0.74)$ & $23.43(1.4)$ & 22.11 \\
\hline RsI-400 & $9.23(0.41)$ & 11.87 (3.37) & $15.23(1.18)$ & 14.14 \\
\hline
\end{tabular}




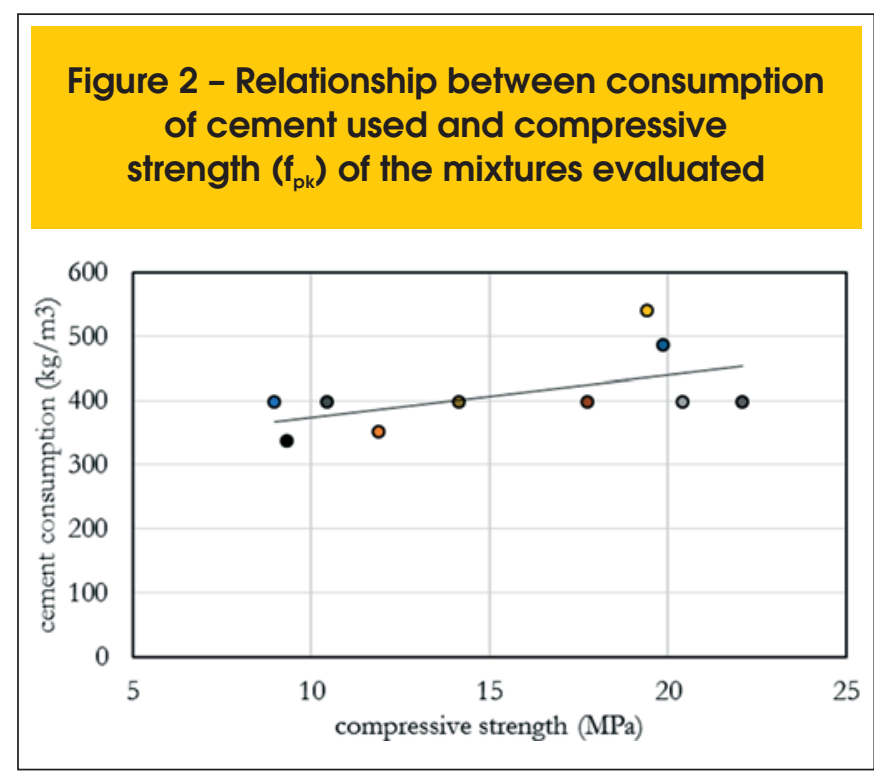

establishes that $f_{p k}$ of concrete used for paving should be $35 \mathrm{MPa}$ for common vehicles and at least $50 \mathrm{MPa}$ for special vehicles that may wear pavements out more easily.

Figure 2 shows that the relationship between $f_{p k}$ and amount of cement used is rather weak, due to the large number of voids typical of pervious concretes.

Also, $f_{p k}$ values for 28 -day-old samples of $\mathrm{N}-400$ and $\mathrm{N}-540$ (with natural aggregate), R-480 (with RCA), and Rs-400 and Rl-400 (with RCA and fiber) were considered suitable ( $20 \pm 3 \mathrm{MPa}$ ). It should be highlighted that the $f_{p k}$ of the mixtures prepared with $100 \%$ RCA was $46 \%$ lower than that of concretes containing natural aggregate, independently of the amount of cement used. However, it is possible to develop concretes containing RCA as aggregate with $f_{p k}$ values similar to those presented by concretes prepared with fiberglass (Rs-400 and RI-400).
Figure 3 - Optical microscopy image of the transition zone between the RCA and the cementitious material (5x magnification)

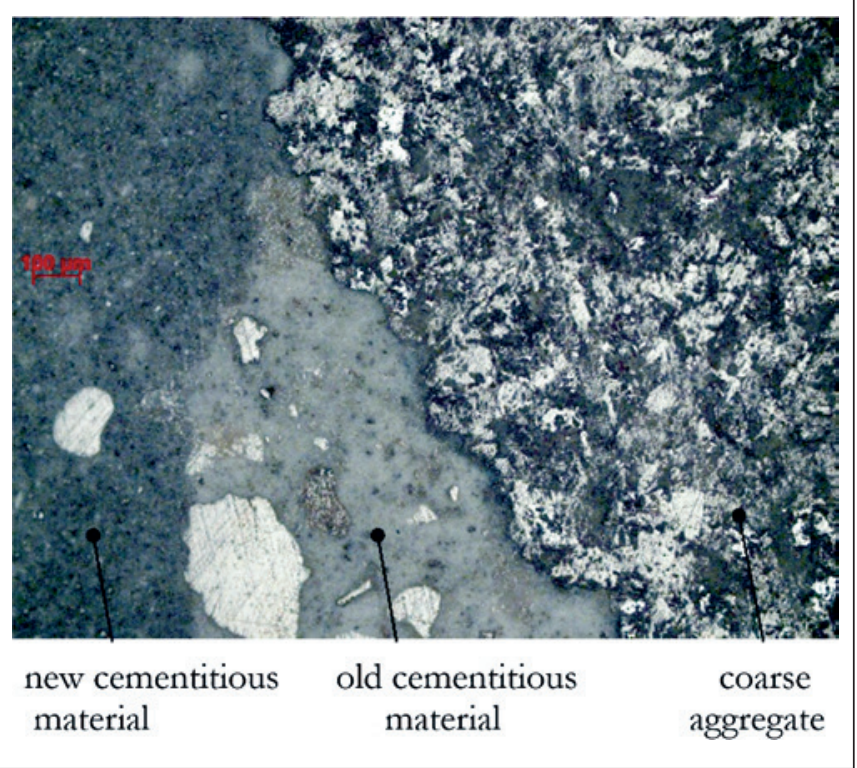

The different $f_{p k}$ values obtained for the mixtures prepared with natural aggregate and RCA ( $\mathrm{N}-400$ and R-400 mixtures) were investigated at microstructural level. Generally, concrete is composed of three phases: the cementitious material, the aggregates, and the transition zones between these. Being critical sites, these transition zones are subject to fissures and to the effects of porosity, when adherence between aggregates and cementitious material may be reduced, affecting the mechanical characteristics of

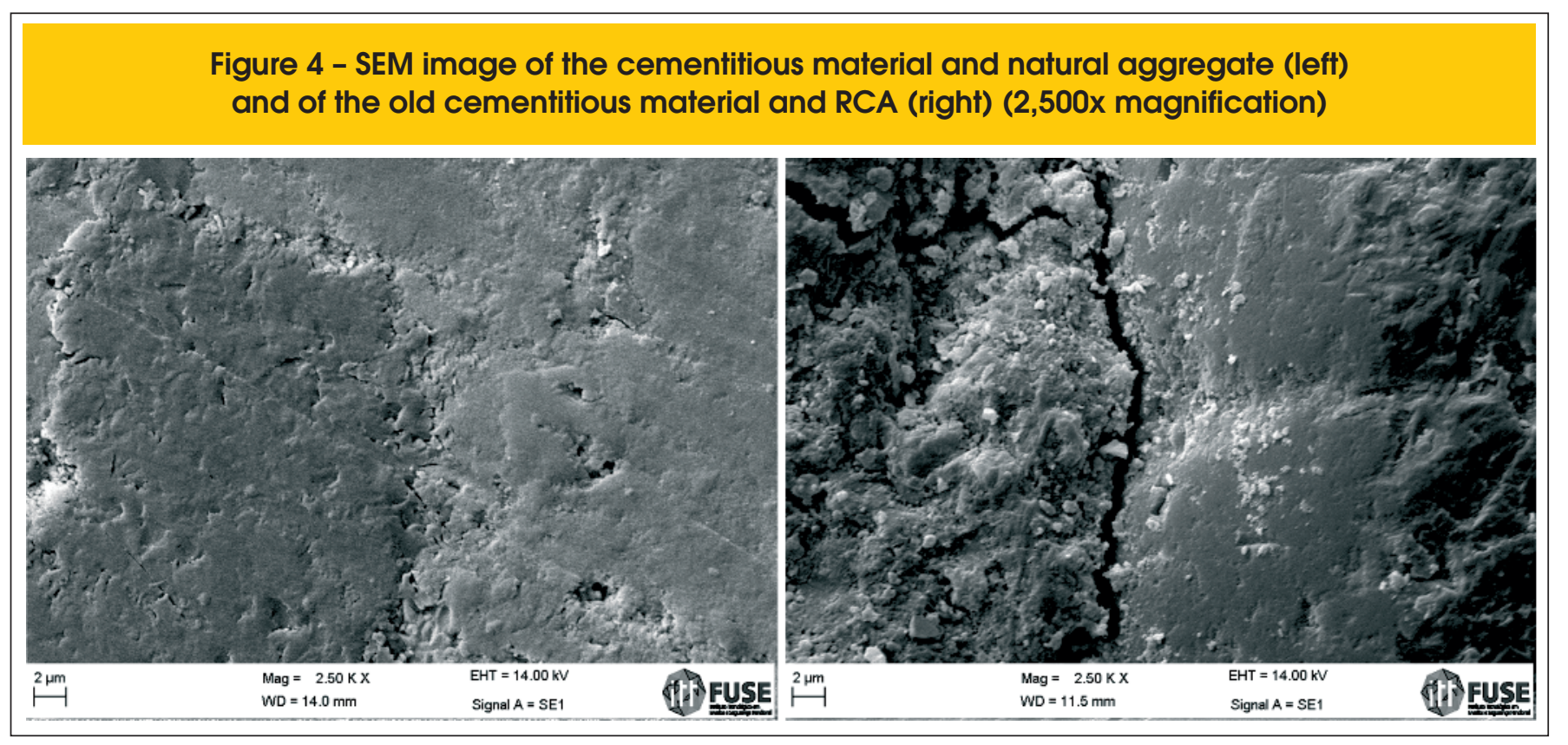


Table 4 - Specific weight and perviousness of set concrete mixtures, and consistency of fresh concretes using the VeBe method. Specific weight values are presented as means followed by the standard deviation. The standard deviation of perviousness values for all mixtures was below 0.002

\begin{tabular}{|ccccc}
\hline Mixtures & w/c & VeBe $(\mathrm{s})$ & Specific weight $\left(\mathrm{g} / \mathrm{cm}^{3}\right)$ & Perviousness $(\mathrm{k})(\mathrm{m} / \mathrm{s})$ \\
\hline N-330 & 0.32 & 5.1 & $2.6(1.69)$ & 0.018 \\
N-350 & 0.32 & 8.0 & $2.9(0.06)$ & 0.015 \\
N-400 & 0.33 & 6.4 & $2.9(0.01)$ & 0.005 \\
N-540 & 0.30 & 7.5 & $2.8(0.02)$ & 0 \\
\hline NR-400 & 0.41 & 6.0 & $2.6(0.09)$ & 0.015 \\
R-400 & 0.41 & 5.8 & $2.3(0.00)$ & 0.016 \\
\hline R-480 & 0.33 & 8.4 & $2.4(0.03)$ & 0.035 \\
Rs-400 & 0.41 & 5.1 & $2.3(0.01)$ & 0.017 \\
Rl-400 & 0.41 & 8.4 & $2.3(0.08)$ & 0.005 \\
Rsl-400 & 0.39 & 8.9 & $2.6(0.08)$ & 0.011 \\
\hline
\end{tabular}

these concretes. Similarly to other composite materials, the bond between two or more elements determines the mechanical properties of cements. In addition, the structure of RCA is more complex than that of natural aggregates due to the two transition zones the aggregate has, one with the old cementitious material, one with the new. In RCA, the existing cementitious material on the transition zone is more porous, has small cracks and therefore the binding properties it affords are weak, critically influencing mechanical resistance. In addition, these pores and cracks tend to require more water, increasing the final amount of the liquid present at the transition zone between the new mixture and RCA [26].

Optical microscopy was used to identify the different transition zones. Using small magnifications, the technique affords to inspect all interfaces involved, that is, the existing aggregate-mixture inter-

\section{Figure 5 - Perviousness coefficient to water of the concrete mixtures investigated}

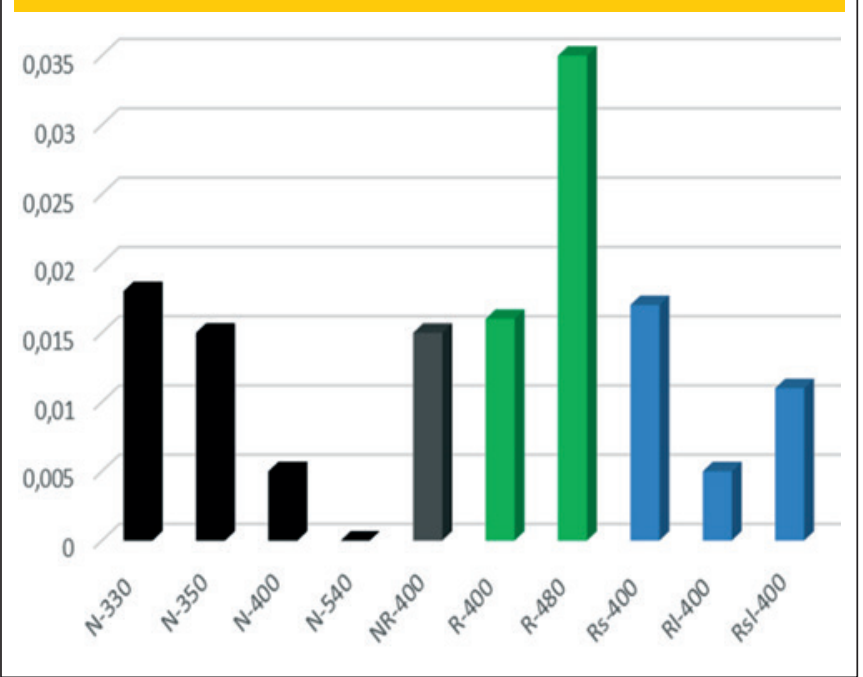

face, the new mixture-aggregate interface, and the contact zone between the new and the existing cementitious materials.

The transition zone between the existing material and the new one is characterized by appropriate binding properties, possibly because the new cementitious material fills the voids, that is, the pores and cracks in the existing material. A different situation is observed between the cementitious material and the aggregate, with dark outlines and cracks in this transition zone. According to Figure 4, mixture R-400 (right) has visible cracks in the transition zone, while mixture $\mathrm{N}-400$ (left) exhibits a more homogeneous transition zone between the natural aggregate and the cementitious material.

In order to inhibit cracks in mixtures prepared with RCA, fiberglass was added, producing the expected behavior.

Water absorption of a cementitious material with RCA is greater than that observed when natural aggregates are used. Therefore, an additional volume of water was required during the preparation of mixtures with recycled aggregate to adjust the water/binder ratio of these mixtures. Workability was determined using a VeBe consistometer, since the slump test is not indicated to evaluate dry cement mixtures. The standard DNIT 064 [27] establishes that when the vibration time observed is $3 \mathrm{~s}$ or less, the results obtained are not representative and workability has to be determined using another method. As shown in Table 4 all values obtained were above $3 \mathrm{~s}$, with mean of $7 \pm 2 \mathrm{~s}$.

The specific weight of concrete mixtures prepared with RCA was a little lower than that of mixtures including the natural aggregate. Figure 5 illustrates the perviousness of the mixtures investigated. Appropriate perviousness values (above $10^{-4} \mathrm{~m} / \mathrm{s}$ ) were observed for all mixtures evaluated, except $\mathrm{N}-540$, due to the high level of cement used, which reduced perviousness of the material to the point of rendering it impervious.

Figure 6 compares the perviousness values of mixtures prepared with the same amount of binder $\left(398 \mathrm{~kg} / \mathrm{m}^{3}\right)$. A marked difference was observed in perviousness values, which varied with the type of aggregate used and the inclusion of fiberglass.

On the whole, perviousness coefficients were higher for concretes 


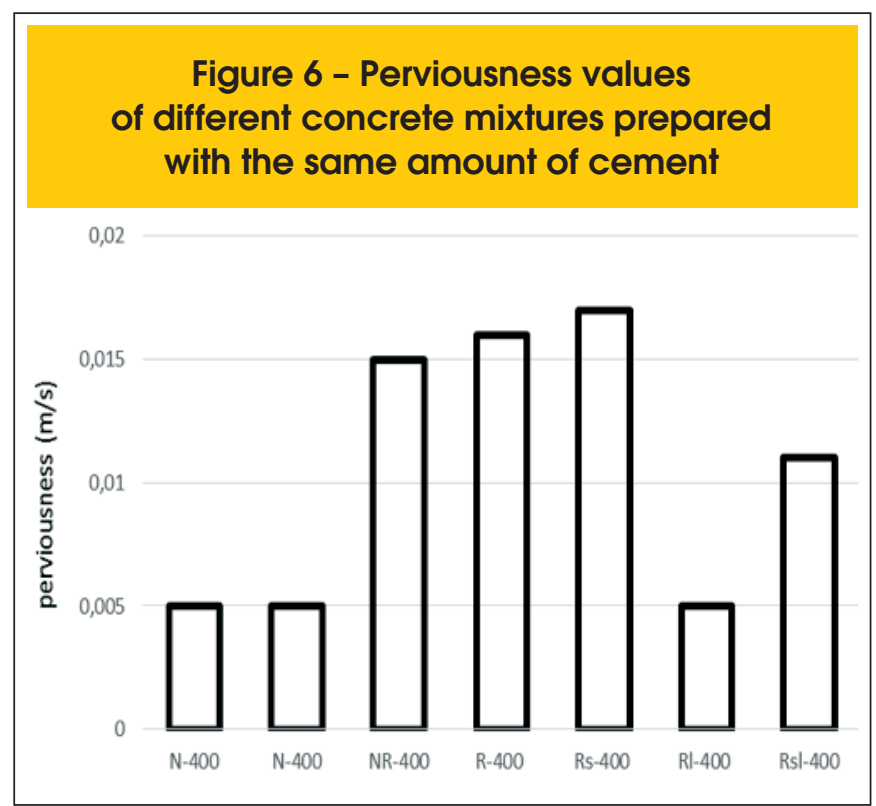

prepared with RCA, except the mixture RI-400. Interestingly, the addition of long fiberglass decreased perviousness of both the RI400 and the Rsl-400 mixtures (the latter prepared with mixed fiber lengths). The mixture R- 400 , which included $50 \%$ of natural aggregate and $50 \%$ of RCA, had a perviousness coefficient a little below that of mixtures containing 100\% RCA (R-400) and considerably higher than that of mixtures with $100 \%$ of natural aggregate.

The relationship between strength and perviousness is extremely important in the preparation of pervious concretes. Figure 7 presents the $f_{p k}$ and perviousness values of the mixtures tested in terms of mechanical performance.

Good results were observed for the mixtures R-480, Rs-400, RI400 , and $\mathrm{N}-400$, which presented acceptable $f_{p k}$ and perviousness values. R-480, prepared with RCA, presented the best performance, but it should be highlighted that this mixture contained high cement amount $\left(485 \mathrm{~kg} / \mathrm{m}^{3}\right)$.

\section{Conclusions}

The present study evaluated the performance of a concrete mixture prepared with RCA for use as pavement based on perviousness, workability, and mechanical strength, in addition to an analysis of the interfaces between the aggregates used and the cementitious material.

SEM analysis revealed lower $f_{p k}$ values of mixtures prepared with RCA, possibly due to the micro-cracks on the aggregatecementitious material interface. However, the addition of fiber improved mechanical performance of these concrete. Interestingly, the transition zone between existing cementitious material in RCA and the new cement mixture is characterized by good adherence. The explanation may lie in the filling of voids (pores and fissures) in the existing material with the new cement mixture.

The $f_{p k}$ values of concrete mixtures R-480, Rs-400, RI-400 and $\mathrm{N}-400$ were around $20 \mathrm{MPa}$, and are considered acceptable. The perviousness coefficient of these mixtures was also considered good. As a rule, higher perviousness coefficients were observed

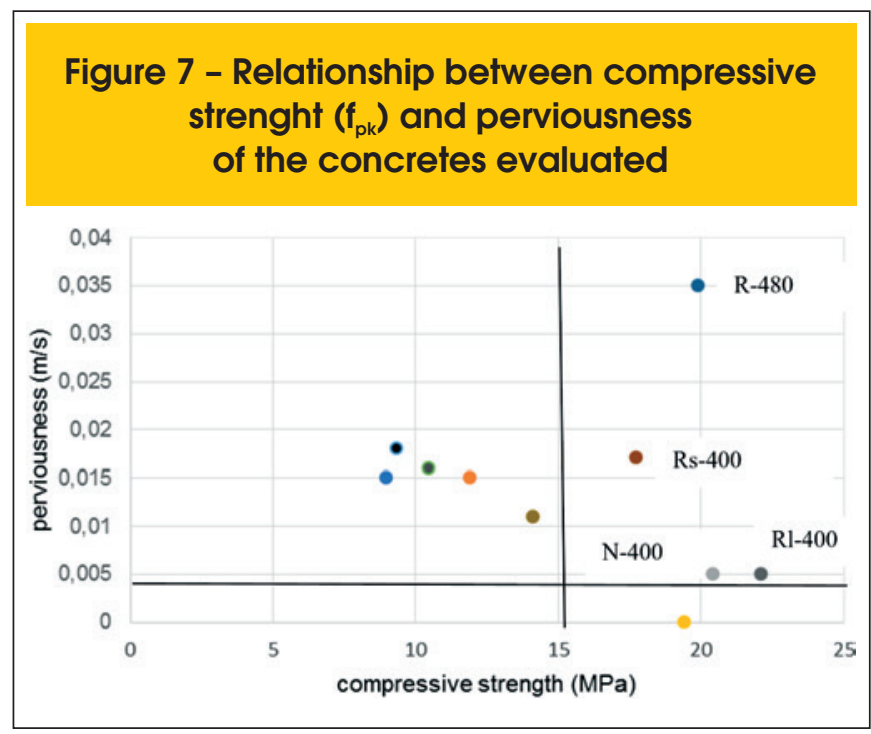

for mixtures prepared with RCA, indicating that this kind of aggregate confers better properties to the final product.

Higher cement content in the preparation of the mixtures studied led to a slight improvement in $f_{p k}$, though the mixtures obtained were less pervious. Significant differences were observed between concrete mixtures of different compositions, for a given amount of cement.

\section{Acknowledgements}

The authors thank CAPES for the post-doc grant to the first author, to the students who helped during the experimental procedure, to Fernanda Colombo and Ismael Mello, and to the Technological Assays and Functional Safety Laboratories (itt Fuse), UNISINOS.

\section{References}

[1] TUCCI, C.E. M. Estimativa do Volume para controle da drenagem no lote. In: Drenagem urbana: Gerenciamento Simulação e Controle, Editora da Universidade ABRH, 1998, p. 155-163, 1998

[2] TUCCI, C. E. M; BERTONI, J. C. Inundações urbanas na América do Sul. Porto alegre: Associação Brasileira de recursos Hídricos, 2003, 150 p.

[3] CAMPANA, N.; TUCCI, C.E.M. Estimativa de área Impermeável de macro bacias urbanas. RBE, Caderno de Recursos Hídricos, v.12, n.2, 1994; p.79-94.

[4] BRASIL, MINISTÉRIO DO MEIO AMBIENTE, CONSELHO NACIONAL DO MEIO AMBIENTE - CONAMA. Resolução no 307, de 05 de julho de 2002. Estabelece diretrizes, critérios e procedimentos para a gestão dos resíduos da construção civil. Diário Oficial da República Federativa do Brasil, Brasília, DF, n 136, 17 de julho de 2002.

[5] PINTO, T. P. Construction Wastes as Raw Materials for LowCost Construction Products. In: First International Conference of CIB, TG 16, Tampa, 1994, proceedings.

[6] OBLA, K. Pervious Concrete for Sustainable Development. Proceedings of the First International Conference on Recent 
Advances in Concrete Technology, Washington, DC, 2007, proceedings.

[7] URBONAS, B., STAHRE, P. Stormwater Best Management Practices and Detention, Englewood Cliffs, New Jersey: Prentice Hall, 1993, 450 p.

[8] GIBBONS, J. Pavements and Surface Materials. University of Connecticut Cooperative Extension, Technical Paper number 8, 1999, p. 1-7.

[9] WU, H., HUANG, B., SHU, X., DONG, Q. Laboratory Evaluation of Abrasion Resistance of Portland Cement Pervious Concrete. J. Mater. Civ. Eng. v. 23, 2011; p. 697-702.

[10] ASSOCIAÇÃO BRASILEIRA DE NORMAS TÉCNICAS. Cimento Portland pozolânico. NBR 5736, Rio de Janeiro, 1999.

[11] ASSOCIAÇÃO BRASILEIRA DE NORMAS TÉCNICAS. Agregados - Determinação da composição granulométrica. NBR NM 248, Rio de Janeiro, 2003.

[12] ASSOCIAÇÃO BRASILEIRA DE NORMAS TÉCNICAS. Agregado graúdo - Determinação da massa específica, massa específica aparente e absorção de água. NBR NM 53, Rio de Janeiro, 2009.

[13] ASSOCIAÇÃO BRASILEIRA DE NORMAS TÉCNICAS. Agregados - Determinação da massa unitária e do volume de vazios. NBR NM 45, Rio de Janeiro, 2006.

[14] PUTMAN, B.J., NEPTUNE, A.I. Comparison of test specimen preparation techniques for pervious concrete pavements. Construction and Building Materials, v. 25, n. 8, 2011; p. 3480-3485.

[15] PINDADO, M. Á., AGUADO, A., JOSA, A. Fatigue behavior of polymer-modified porous concretes. Cement and Concrete Research, v. 29, n. 7, 1999; p. 1077-1083.

[16] HASELBACH, L. M., VALAVALA, S., MONTES, F. Permeability predictions for sand-clogged Portland cement pervious concrete pavement systems. Journal of Environmental Management, v. 81, n. 1, 2006; p. 42-49.

[17] SCHAEFER, V. R., WANG, K., SULEIMAN, M. T., KEVERN, J. T. Mix Design Development for Pervious Concrete in Cold Weather Climates. Ames, IA, National Concrete Pavement Technology Center, Final Report, February 2006.

[18] JOUNG, Y. M. Evaluation and optimization of pervious concrete with respect to permeability and clogging. Thesis. Texas A\&M University. December 2008.

[19] AMERICAN CONCRETE INSTITUTE. Guide for Selecting Proportions for No-Slump Concrete. ACI 211.3R, Farmington Hills, 2002.

[20] DEPARTAMENTO NACIONAL DE INFRAESTRUTURA DE TRANSPORTES. Pavimento rígido - Determinação da consistência do concreto pelo consistômetro $\mathrm{VeBe}-$. Método de ensaio. DNIT 064, Rio de Janeiro, 2004.

[21] ASSOCIAÇÃO BRASILEIRA DE NORMAS TÉCNICAS. Concreto - Ensaios de compressão de corpos-de-prova cilíndricos. NBR 5739, Rio de Janeiro, 2007.

[22] ASSOCIAÇÃO BRASILEIRA DE NORMAS TÉCNICAS. Peças de concreto para pavimentação - Especificação e métodos de ensaio. NBR 9781, Rio de Janeiro, 2013.

[23] ASSOCIAÇÃO BRASILEIRA DE NORMAS TÉCNICAS. Argamassa e concreto endurecidos - Determinação da absorção de água, índice de vazios e massa específica. NBR 9778, Rio de Janeiro, 2009.
[24] ASSOCIAÇÃO BRASILEIRA DE NORMAS TÉCNICAS. Solo - Determinação do coeficiente de permeabilidade de solos argilosos a carga variável. NBR 14545, Rio de Janeiro, 2000.

[25] AMERICAN CONCRETE INSTITUTE. Pervious Concrete. ACI 522R, Farmington Hills, 2006.

[26] TAM, V. W. Y., GAO, X .F., TAM, C. M. Microstructural analysis of recycled aggregate concrete produced from two-stage mixing approach. Cement and Concrete Research, v. 35, 2005; p. 1195- 1203.

[27] DEPARTAMENTO NACIONAL DE INFRAESTRUTURA DE TRANSPORTES. Pavimento rígido - Determinação da consistência do concreto pelo consistômetro VeBe - Método de ensaio. DNIT 064, Rio de Janeiro, 2004. 